\title{
No-tillage as compared to tillage practices in dry-land farming of a semi-arid climate
}

\author{
E. Stibbe ${ }^{1}$ and D. Ariel ${ }^{2}$ \\ Received : 4 August 1970
}

\begin{abstract}
Summary
The no-tillage practice compared to three conventional tillage practices in autumn on wheat stubble has been tried out in field experiments under conditions of dry-land farming in a semi-arid climate. The influence of the no-tillage practice on soil and weed control during winter fallow and growth behavior of two summer crops is discussed in relation to conventional tillage practices. Yield responses of the summer crops sorghum and cotton are given. Yields of follow-up crops in the three-year crop sequence of winter small grains (winter fallow - spring or summer crop - winter legume for forage) were indicative for the residual effects of no-tillage and tillage practices on soil and weed growth.
\end{abstract}

\section{Introduction}

Mechanization in Israeli agriculture has tremendously contributed in reducing the amount of man hours and in opening possibilities of extending the cultivated acreage. Only quite recently research in tillage practices has been under way in this country. The most urgent subject for research was in the sector of dry-land farming comprising an acreage of 200,000 ha, which is about half of the total arable acreage with a net return of only $25 \%$ of that from the irrigated acreage. Considering now that in dryland farming plowing is a standard practice and therefore tillage expenses make up for 20 to $30 \%$ of the total expenses in an agricultural undertaking with only marginal net returns for the farmers as an average over the years. It seems therefore important to determine where the limits are in the sector of soil tillage in dry-land farming. Here this will be only considered from the agro-technical point of view, without entering in the domain of economics, which varies so greatly from country to country.

Studies from the last decade show that experience has been gained with no-tillage practices. However most experiences were obtained from experiments in the humid climate, where rainfall occurs during the growing season. The practice of no-tillage consists here of either planting corn in a chemically killed sod, or planting in a chemically killed cover crop, or planting in the trash of previously grown corn (Harrold et al., 1970; Shear and Moschler, 1969). Studies with other crops have been reported (Bakermans et al., 1968; Philips, 1968). This type of no-tillage, which leaves a large amount of crop residues on the field, necessitates far reaching technical changes in the planter equipment to enable successful planting. It was found that keeping a large 
amount of mulch on the soil surface improved water infiltration, conserved soil moisture and prevented excessive run-off (Jones et al., 1969; Triplett et al., 1968). One of the problematic factors seems to be weed control by selective herbicides, which is an essential feature of no-tillage practices. The problem is twofold, in the first place the common herbicides in use are ineffective with respect to some persistent kind of weeds and secondly there always remains the potential danger from residual effects of herbicides on the follow-up crops (Wicks et al., 1969).

The application of no-tillage in a semi-arid climate is somewhat different from that of a no-tillage practice in the humid climate. Here a chemical treatment of the winter fallow with suitable persistent herbicides enables the introduction of no-tillage in a dry-land crop sequence. This eliminates late summer tillage and cultivations during the winter and spring season, without reducing soil moisture or yield. In general the quantity of crop residues is much less than in a humid climate. Hence after a chemically treated winter fallow, no special changes in planter equipment seems to be necessary for obtaining a successful planting. Studies also show that the crop residue reduced the loss of topsoil moisture, but did not contribute to a larger soil moisture storage. The better moisture characteristics of the topsoil with a crop residue was supposed to be important for seedling emergence in dry hot weather in spring (Army et al., 1961; Philips, 1964; Wiese et al., 1969).

The following paper, partly from experimental data, partly from observations, deals with the possibilities of no-tillage compared to tillage practices towards a dry-land summer crop and its follow-up crops, in some respects different from those reported in the USA and elsewhere.

\section{Climate, soils, crop rotation and standard tillage practices in dry-land farming}

\section{Climate and soils}

In spite of better adopted crop varieties, fertilizer recommendations and our knowledge about moisture requirements of crops as influenced by climatic conditions, the limiting factor for obtaining economical yields in the semi-arid areas still is the unpredictable amount of rainfall during winter. Whereas winter crops are to a certain extent dependent on the frequency and intensity of rainfall, summer crops are entirely dependent on the total accumulated amount of soil moisture, since no rainfall occurs during the growing season. From north to south a gradual decrease in annual precipitation can be observed over the most important agricultural area. In the northern area precipitation is $600 \mathrm{~mm}$ and more, while in the south it is $300 \mathrm{~mm}$ and less. Frequency and severeness of drought years vary in the same way from once in five years in the north to once in three years in the south. Soils can be roughly divided into three groups: in the north clays, in the middle clays and sands and in the south loams and sandy loams (löss).

\section{Dry-land crop sequence}

The crop sequence for dry-land farming is to a certain extend flexible dependent on the amount of rainfall. A drier winter or drought winter can change the choice between summer crops (cotton, sorghum) or compels the farmer to skip a summer crop an to grow again wheat, which is planted prior to the coming winter season. Essentially a three-year crop rotation consists of: 1 . winter-grown small grains; 2 . winter fallow and spring or summer crop; 3 . winter legumes for forage. The choice in num- 
ber of crops is larger in the north than in the south. In practice the most responsive crops towards tillage are cotton, sunflowers and chickpeas. The choice of crops are:

$\begin{array}{lll}\text { Winter crops } & \begin{array}{l}\text { North } \\ \text { wheat } \\ \text { vetch } \\ \text { clovers }\end{array} & \begin{array}{l}\text { South } \\ \text { wheat } \\ \text { vetch }\end{array} \\ \text { Spring crops } & \begin{array}{l}\text { sunflowers } \\ \text { chickpeas }\end{array} & \text { (chickpeas) } \\ \text { Summer crops } & \begin{array}{l}\text { cotton } \\ \text { sorghum } \\ \text { corn }\end{array} & \begin{array}{l}\text { (cotton) } \\ \text { sorghum }\end{array} \\ \end{array}$

Phosphate fertilizer is applied to legume crops (vetch, chickpeas) in sufficient amounts to keep the abailability of phosphate at a proper level for the whole crop sequence. Nitrogen fertilizer is applied in split dressings to the wheat crop. The total amount of fertilizers given in a three-year crop sequence comes to $50-60 \mathrm{~kg} \mathrm{P}$ and $90-100 \mathrm{~kg}$ $\mathrm{N}$ per ha.

\section{Tillage practices}

Soil tillage in practice is performed prior to the onset of the rains on the stubble of a winter grown wheat crop or after a forage crop. The wheat stubble mostly is burnt before tillage. The main purpose of tillage is to obtain a weed-free suitable seedbed for spring and summer crops. The tilled soil is winter fallowed, cultivated or herbicide treated to control weeds during winter. A seedbed preparation is generally obtained by cultivating or harrowing.

At the time of tillage at the end of the summer season the moisture content of the soil on dry-land fields reaches the hygroscopic moisture percentage over the depth of tillage, and therefore tillage requires a high power input. From a European point of view it may be questioned why tillage is not performed during the winter season. For practical reasons tilling the soil in the winter season constitutes a risk since all the rainfall is concentrated in the five winter months. When there is an interval between the rains, it is rather difficult for large fields to decide upon the suitable moment. The conditions for tilling the fields at this critical moment will be to avoid damage to soil structure and to select that state of profuse weed growth, which ensures effective weed control and which avoids interference with the plowing operation. The depth of autumn plowing or subsoiling varies between 20 to $40 \mathrm{~cm}$. Plows in use are 3 to 5 bottom, 12" to $16^{\prime \prime}$ moldboard-type trailed plows without further attachments such as coulters and jointers. Sometimes heavy cultivators (Grubber) are in use. Data compiled from reported results obtained from dynamometer measurements during tillage of dry-land wheat stubble on three trial fields, indicate the high energy requirements in general for tillage and an energy increase of about 40 to $50 \%$, when the depth of plowing is increased from 25 to $40 \mathrm{~cm}$ (Hillel et al., 1969). The latter depth of $40 \mathrm{~cm}$ went below the depth of previous plowing and includes a plowplan (Table 1). This high energy requirement for tilling the dry-land soil necessitates the use of crawler tractors of the Caterpillar D-4 type, being a high investment in implements for a comparatively limited use at the farm. 
Table 1 Relative mean energy requirements per unit tilled area (or relative mean force per unit width of operation) on dryland wheat stubble on grumusol type of soil (sorghum trial)

\begin{tabular}{lccccc}
\hline $\begin{array}{l}\text { Type of } \\
\text { tillage }\end{array}$ & $\begin{array}{c}\text { Depth of } \\
\text { tillage } \\
(\mathrm{cm})\end{array}$ & 1965 & 1966 & Relative mean energy per unit tilled area \\
& & & & 1967 & Average \\
Plowing 1 & 40 & 100 & 100 & 100 & 100 \\
Plowing & 25 & 43 & 46 & 72 & 54 \\
Subsoiling $^{3}$ & 40 & 78 & 87 & 102 & 89 \\
\hline
\end{tabular}

13 bottom, 16" moldboard plow, trailed.

24 bottom, 14"' moldboard plow, trailed.

s 3 heavy shanks arrangement on two tool bar carrier, with a shank spacing of $40 \mathrm{~cm}$ in 1965 , $50 \mathrm{~cm}$ in 1966 and $45 \mathrm{~cm}$ in 1967.

1 $100 \%=3800 \mathrm{kgm} / \mathrm{m}^{2}$ in $1965 ; 4857 \mathrm{kgm} / \mathrm{m}^{2}$ in $1966 ; 2242 \mathrm{kgm} / \mathrm{m}^{2}$ in 1967 .

\section{Effect of tillage on the soil}

Late summer tillage of dry-land fields results in at random arrangement of large, more or less overturned soil blocks, filled in with some smaller aggregates of the topsoil layer. The pattern completely differs from that of a tilled field in the humid zone. Prior to tillage the soil surface shows a roughly polygonal cracking of the soil extending to a depth of 60 to $80 \mathrm{~cm}$ (Fig. 1). The plowshare cuts the soil blocks from underneath and the moldboard itself has little effect in breaking the soil blocks into smaller aggregates otherwise than along the existing crack system (Fig. 2).

Dry sieving data of the tilled soil show no differences between the relative aggregate

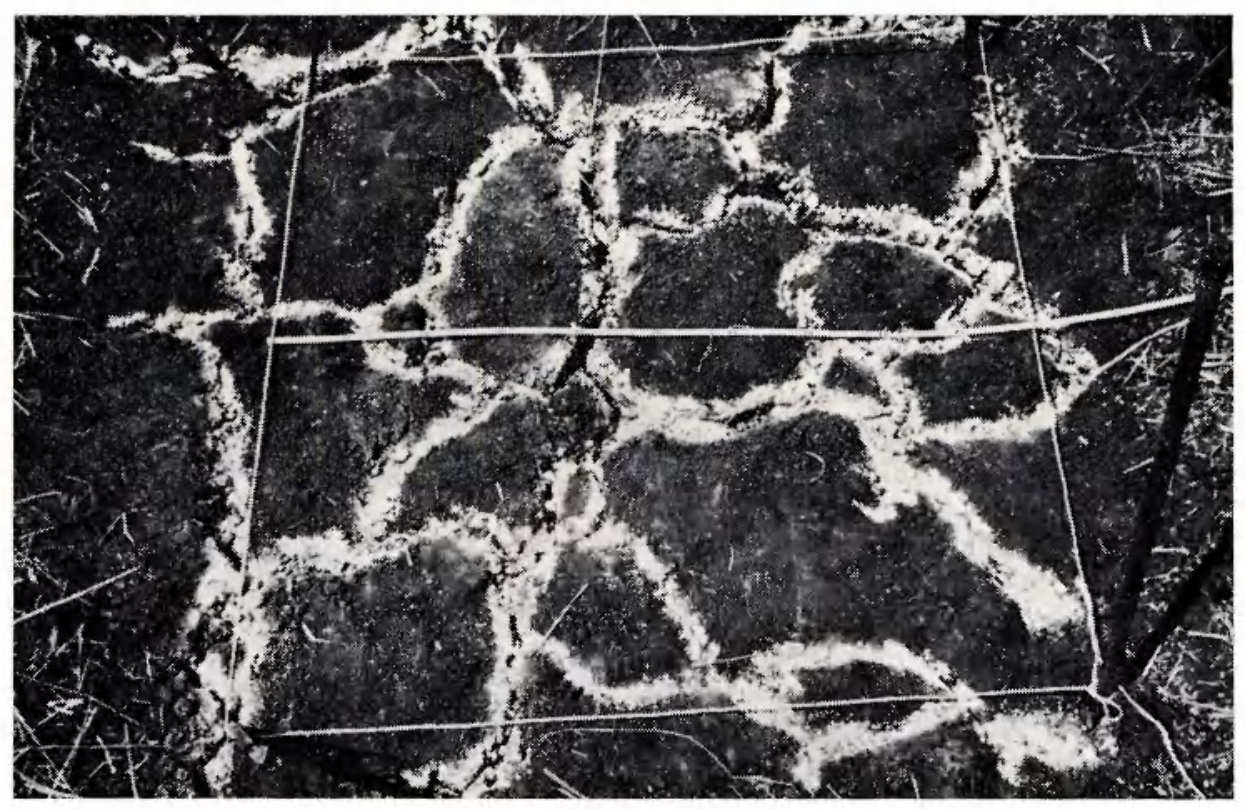

Fig. 1 Cracking pattern of a grumosol indicated by talk powder on $1 \mathrm{~m}^{2}$, prior to tillage. 


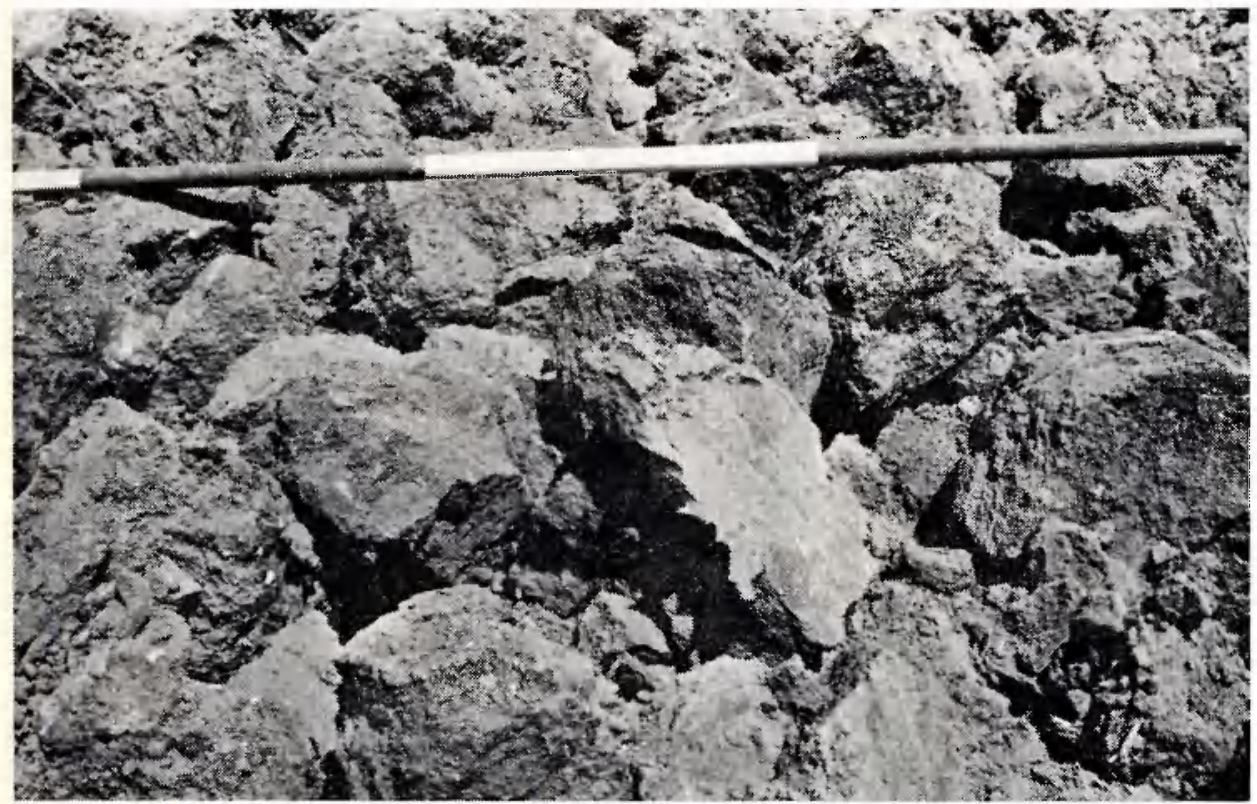

Fig. 2 Close-up of clod arrangement after fall plowing. Scale units on rod: $50 \mathrm{~cm}$.

weight distribution of the various tillage implements used (Hillel et al., 1969). The data are given in Table 2.

Tillage seems thus to result in an at random changing of the soil-block configuration and expanding of the space between them, as compared to the non-tilled soil. It may be questioned now if the invested energy for tilling the soil has a pertinent effect on the yield of a summer crop and follow-up crops as compared to a no-tillage practice.

Crop residue left on the soil surface by a no-tillage practice

The general practice is to burn wheat stubble prior to tillage. This practice is supposed to minimize the carrying over of plant diseases and to restrict the population of field rodents. The turning over of crop residues seems to have no effect in raising the organic matter content of soils in the semi-arid climate. The plowed layer of most soils do not contain more than 0.5 to $1.0 \%$ organic matter except for hydromorphic soils where the organic matter content may reach 2 to $3 \%$.

The field experiments where no-tillage had been included as one of the treatments

Table 2 Relative weight distribution of aggregates by dry sieving of the tilled soil (sorghum trial)

\begin{tabular}{|c|c|c|c|c|c|c|c|c|c|}
\hline \multirow{2}{*}{$\begin{array}{l}\text { Type of } \\
\text { tillage }\end{array}$} & \multirow{2}{*}{$\begin{array}{c}\text { Depth of } \\
\text { tillage } \\
(\mathrm{cm})\end{array}$} & \multicolumn{4}{|c|}{ Aggregate weight fractions (\%) } & according & to screen & \multicolumn{2}{|c|}{ openings $(\mathrm{cm})$} \\
\hline & & $<0.5$ & $0.5-1.0$ & $1.0-2.0$ & $2.0-3.0$ & $3.0-4.0$ & $4.0-5.0$ & $5.0-9.0$ & $>9.0$ \\
\hline Plowing & 40 & 19.8 & 6.0 & 6.9 & 5.8 & 3.7 & 2.5 & 5.6 & 49.9 \\
\hline Plowing & 25 & 17.5 & 4.1 & 4.8 & 4.8 & 3.4 & 2.7 & 8.2 & 54.5 \\
\hline Subsoiling & 40 & 21.4 & 5.7 & 6.7 & 6.6 & 4.2 & 3.8 & 9.8 & 41.9 \\
\hline
\end{tabular}


versus tillage treatments were carried out in late summer on wheat stubble fields. The amount of crop residue left on the field without baling of the straw comes to 3000 to $5000 \mathrm{~kg} / \mathrm{ha}$ and with baling to 1000 to $2000 \mathrm{~kg} / \mathrm{ha}$, which still gives a fairly satisfactory protection of the soil surface during winter. However normally no straw stubble will be left on the field.

Weed control and accumulated soil moisture during and after winter fallow

The advantage of autumn plowing is that it leaves the field clean of winter weeds and volunteer wheat during the better half of the winter. The decision and timing of weed control either by cultivating or applying herbicides becomes less urgent compared to that of the subsoiled and no-tillage fields. No-tillage should be carefully observed in order to apply the herbicidal treatment at the most effective stage of weed growth. It could be observed that the more crop residue is left on the soil surface, the less effective weed control is and the higher concentrations of herbicide should by applied.

The residual effect of herbicide applied early in the winter on no-tillage fields can be disastrous for the follow-up crops if the winter turns out to be a drought winter. For instance $2 \mathrm{~kg}$ Atrazine per ha applied to no-tillage in a drought year caused the failure of the winter-grown wheat crop following the sorghum summer crop. This risk becomes greater the farther south of the $400 \mathrm{~mm}$ rainfall region no-tillage practices are introduced.

The actual break-up of the large soil blocks on tilled fields is being achieved by the wetting and slaking action of successive rains during the winter season. Further breakup and levelling is obtained by cultivating or harrowing for weed control and seedbed preparation. This secondary tillage on wet soil causes a certain amount of soil compaction by tractor wheels and the implements. The initial wetting of the soil blocks of a tilled field by the first rains is to a large extent lost during dry spells between the rains as a result of the soil surface roughness. However later on the better infiltration properties of a tilled soil are obvious as compared to the no-tillage field (Hillel et al., 1969). (See Table 3.)

Table 3 Soil moisture (\%) by weight of tilled and no-tillage fields during and after winter fallow (sorghum trial). Means of two samples per treatment in four replications

\begin{tabular}{|c|c|c|c|c|c|}
\hline \multirow[t]{2}{*}{ Period } & \multirow[t]{2}{*}{ Treatment } & \multicolumn{4}{|c|}{ Soil moisture (\%) at depth } \\
\hline & & \multicolumn{2}{|c|}{$0-30 \mathrm{~cm}$} & $30-60 \mathrm{~cm}$ & $60-90 \mathrm{~cm}$ \\
\hline After rainfall November & $\begin{array}{l}\text { Plowed } \\
\text { No-tillage }\end{array}$ & \multicolumn{2}{|c|}{$\begin{array}{l}39.2 \\
34.4\end{array}$} & $\begin{array}{l}25.2 \\
18.6\end{array}$ & $\begin{array}{l}20.1 \\
18.5\end{array}$ \\
\hline After dry spell December & $\begin{array}{l}\text { Plowed } \\
\text { No-tillage }\end{array}$ & \multicolumn{2}{|c|}{$\begin{array}{l}24.2 \\
23.6\end{array}$} & $\begin{array}{l}23.5 \\
20.3\end{array}$ & $\begin{array}{l}22.0 \\
17.4\end{array}$ \\
\hline \multirow[t]{2}{*}{ At seedling emergence May } & $\begin{array}{l}\text { Plowed + } \\
\text { cultivated }\end{array}$ & $\begin{array}{r}0 / 10 \\
10 / 20 \\
20 / 30\end{array}$ & $\begin{array}{l}16.8 \\
29.6 \\
33.2\end{array}$ & 31.4 & 31.9 \\
\hline & No-tillage & $\begin{array}{r}0 / 10 \\
10 / 20 \\
20 / 30\end{array}$ & $\begin{array}{l}22.5 \\
25.0 \\
27.1\end{array}$ & 28.4 & 30.1 \\
\hline
\end{tabular}

15 bar suction P.W.P. $=15.0 \%$ soil moisture by weight $; 1 / 3$ bar suction F.C. $=26.0 \%$ soil moisture by weight. 
On the other hand the soil moisture content of the $10 \mathrm{~cm}$ planting layer, which is of importance to germination and seedling emergence, is higher for the no-tillage treatment than for the plowed soil. However below this $10 \mathrm{~cm}$ layer, soil moisture is higher for the plowed and cultivated field.

\section{Effect of tillage on crops}

\section{Differences in planting conditions and seedling emergence between tilled and} no-tillage fields

Sorghum is planted generally at the end of March or the beginning of April, and cotton in April. No special difficulties were encountered in planting sorghum or cotton with a commercial type of planter in the no-tillage fields. Some care had to be taken to adjust the double-disk furrow openers or simple furrowers as trash dividers. Since the soil surface is level and compacter (Fig. 3), a more even and uniform distribution and depth of seed planting is achieved than in the case of fallowed plowed land (Fig. 4). The shallow depth to be opened for planting by the furrow openers at a notillage field, because of the higher soil moisture content of the surface layer, achieves a comparatively shallower planting depth with respect to the original soil surface. Though not measured, it may be assumed that soil-seed contact and temperature conditions of a no-tillage field are nearer optimum for germination and emergence than those of a tilled field in dry hot spring weather. The last assumption can be based upon the earlier seedling emergence and better initial plant stand of the no-tillage field, which are shown in Table 4 (Hillel et al., 1969; Stibbe and Ariel, 1970). Though

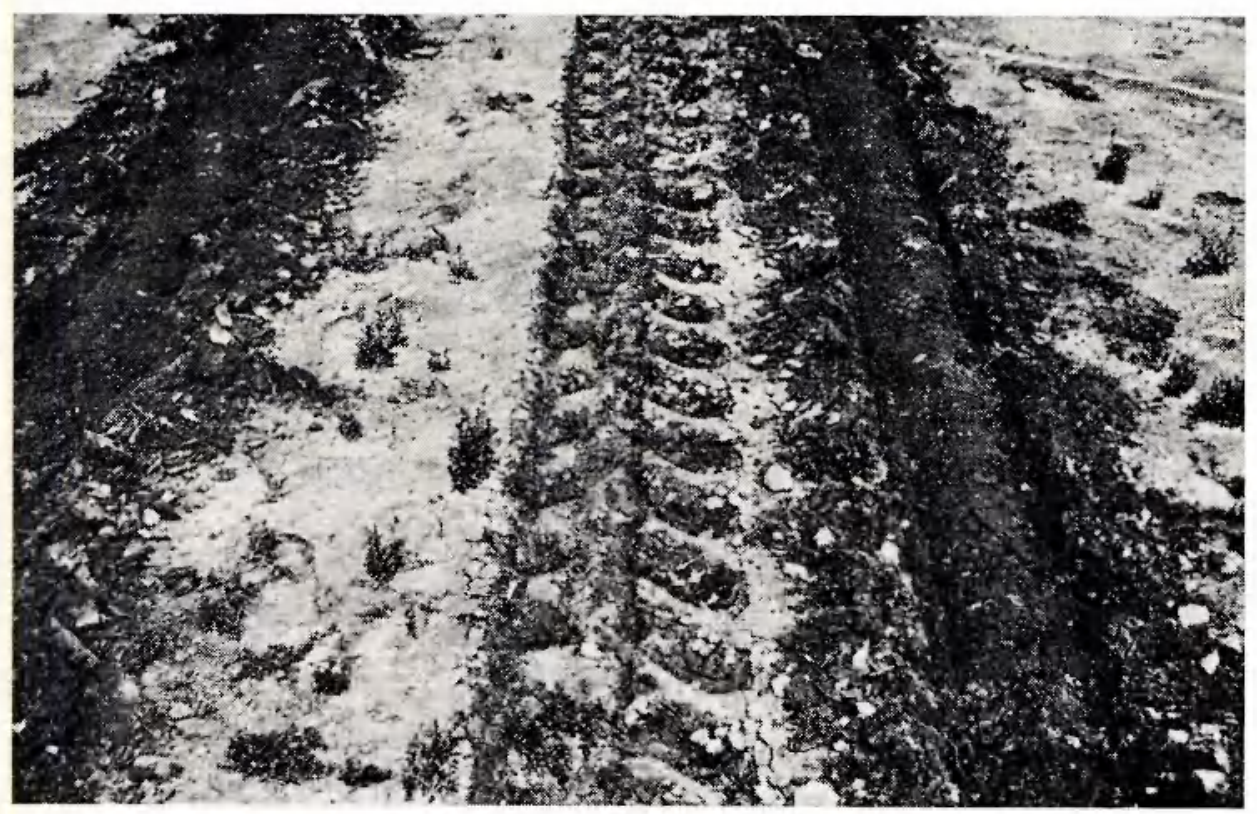

Fig. 3 Level and compact seedbed after no-tillage. 


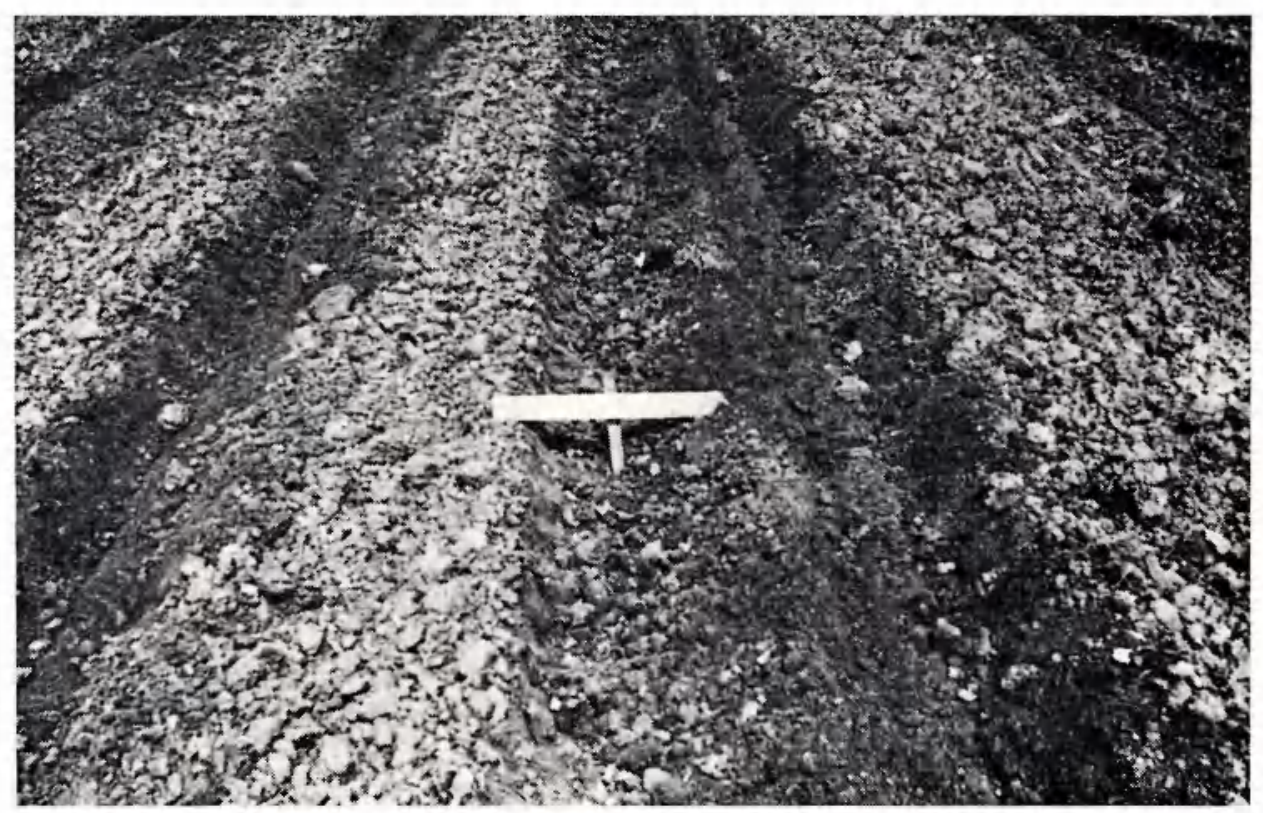

Fig. 4 Loose seedbed with wheeltracks after plowing.

differences exist in number of emerged cotton plants, its importance is only minor, since the cotton crop possesses a high flexibility towards the number of emerged seedlings and its influence on yield performance.

This trend may be reversed when a freak rainfall after planting occurs.

\section{Differences in root growth and soil compaction}

The better initial start in germination and seedling growth of the no-tillage with respect to the tilled treatments is lost after the first month, when the plants on the no-tillage treatment show some characteristic yellowing of the leafs and retarded growth. The higher soil density and mechanical soil resistance, combined likely with a lower nitrogen availability, are limiting the root development in the topsoil layer and later on the downward root growth. Washed and dried sorghum roots from soil samples taken

Table 4 Initial stands of emerged seedlings of sorghum and cotton

\begin{tabular}{|c|c|c|c|c|c|}
\hline \multirow[t]{2}{*}{$\begin{array}{l}\text { Type of } \\
\text { tillage }\end{array}$} & \multirow{2}{*}{$\begin{array}{c}\text { Depth of } \\
\text { tillage } \\
\text { (cm) }\end{array}$} & \multicolumn{2}{|c|}{$\begin{array}{c}\text { Weed control }+ \text { seedbed } \\
\text { preparation }\end{array}$} & \multicolumn{2}{|c|}{$\begin{array}{l}\text { Number of seedlings } \\
\text { per meter row length }\end{array}$} \\
\hline & & & & sorghum '67 & cotton ' 69 ' \\
\hline Plowing & 40 & cultivated & harrowed & 11.2 & 12.2 \\
\hline Plowing & 25 & cultivated & harrowed & 12.6 & 12.6 \\
\hline Subsoiling & 40 & cultivated & harrowed & 12.7 & 12.8 \\
\hline No-tillage & - & herbicide & - & 13.5 & 13.4 \\
\hline
\end{tabular}

1 Tilled fields for cotton were treated with a herbicide in winter fallow and harrowed for seedbed preparation. 
Table 5 The relative dry root weight distribution in \% with depth from mature sorghum crop (sorghum trial)

\begin{tabular}{ccccc}
\hline $\begin{array}{c}\text { Depth of } \\
\text { soil layer } \\
(\mathrm{cm})\end{array}$ & $\begin{array}{c}\text { Plowed } \\
\text { at }\end{array}$ & $\begin{array}{c}\text { Plowed } \\
\text { at }\end{array}$ & $\begin{array}{c}\text { Subsoiled } \\
\text { at }\end{array}$ & No-tillage \\
& $40 \mathrm{~cm}$ & $25 \mathrm{~cm}$ & $40 \mathrm{~cm}$ & \\
$0-30$ & & & & \\
$30-60$ & 20.1 & 29.7 & 18.9 & 15.9 \\
$60-90$ & 23.4 & 17.9 & 16.4 & 8.3 \\
$90-120$ & 24.6 & 11.9 & 13.1 & 9.7 \\
$120-150$ & 20.6 & 13.8 & 12.0 & 6.6 \\
$150-180$ & 10.8 & 8.8 & 15.3 & 7.1 \\
$0-180$ & 0.5 & 5.7 & 4.2 & 2.9 \\
& 100.0 & 87.8 & 79.9 & 50.5 \\
\hline
\end{tabular}

in the center between mature plant rows, are given as the relative root distribution with depth in Table 5 (Hillel et al., 1969).

The more uniform and dense root growth of plowing at $40 \mathrm{~cm}$ depth treatment is apparent when it is compared to plowing at $25 \mathrm{~cm}$, subsciling at $40 \mathrm{~cm}$ and no-tillage. The impeding effect of soil resistance on root growth could be easily demonstrated on the taproot growth of cotton, which shows a sideways deviating taproot the moment the taproot encounters a compact layer or tillage pan during its growth (Fig. 5) Extracting 60 mature plants at random from each treatment, the depth of the taproot deviation and the frequency of occurrence with depth could be found (Stibbe and Ariel, 1970). Data obtained are given in Table 6.

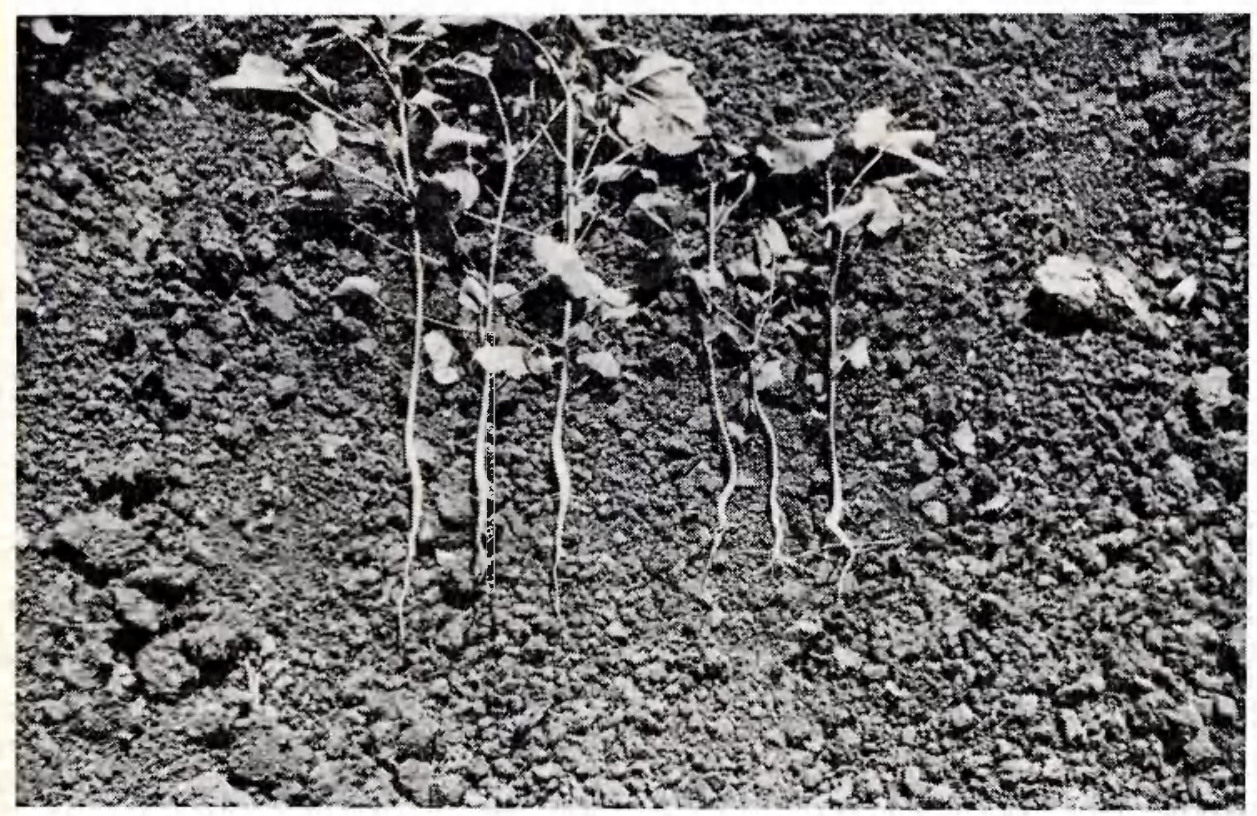

Fig. 5 Well-developed cotton plants with straight taproots grown on plowed soil (left) and smaller plants with distorted roots on untilled soil (right). 
Table 6 The distribution of the number of cotton plants showing abnormal taproot growth and depth of occurrence (cotton trial)

\begin{tabular}{|c|c|c|c|c|}
\hline $\begin{array}{l}\text { Depth of } \\
\text { soil layer } \\
\quad(\mathrm{cm})\end{array}$ & $\begin{array}{c}\text { Plowed } \\
\text { at } \\
40 \mathrm{~cm}\end{array}$ & $\begin{array}{c}\text { Plowed } \\
\text { at } \\
25 \mathrm{~cm}\end{array}$ & $\begin{array}{c}\text { Subsoiled } \\
\text { at } \\
40 \mathrm{~cm}\end{array}$ & No-tillage \\
\hline $0-5$ & 0 & 0 & 0 & 0 \\
\hline $5-10$ & 2 & 0 & 0 & 4 \\
\hline $10-15$ & 2 & 5 & 14 & 20 \\
\hline $15-20$ & 7 & 91 & $17^{1}$ & 13 \\
\hline $20-25$ & 71 & $20^{2}$ & 8 & 5 \\
\hline $25-30$ & 5 & 9 & 5 & 7 \\
\hline $30-35$ & 32 & 1 & $1^{2}$ & 1 \\
\hline $35-40$ & 5 & 2 & 0 & 2 \\
\hline $40-45$ & 0 & 0 & 0 & 0 \\
\hline $\begin{array}{l}\text { Number of affected } \\
\text { plants }\end{array}$ & 31 & 46 & 45 & 52 \\
\hline $\begin{array}{l}\% \text { of affected } \\
\text { plants }\end{array}$ & 51.7 & 76.7 & 75.0 & 86.7 \\
\hline
\end{tabular}

1 Depth of cultivation pan; 2 Depth of autumn tillage.

Soil compaction caused by cultivation for seedbed preparation and the depth of autumn tillage has more influence on the $25 \mathrm{~cm}$ plowed, and the $40 \mathrm{~cm}$ subsoiled treatments than on the $40 \mathrm{~cm}$ plowed treatments. On the no-tillage fields the shallow compacted layer caused by disking and traffic of the previously grown wheat crop strongly impeded the downward taproot growth and only about $13 \%$ of the taproots were able to penetrate deeper than $40 \mathrm{~cm}$.

Results from penetrometer determinations of the same experiment at the time of seedling emergence, indicate the depth of the various compacted layers and their differences in resistance to penetration at high soil moisture content (Stibbe and Ariel, 1970) (Table 7).

Table 7 Resistance to penetration recorded as the number of hammer blows per $5 \mathrm{~cm}$ depth in the plant row at the time of seedling emergence ${ }^{1}$

\begin{tabular}{ccccc}
\hline $\begin{array}{c}\text { Depth of } \\
\text { soil layer }\end{array}$ & $\begin{array}{c}\text { Plowed } \\
\text { at }\end{array}$ & $\begin{array}{c}\text { Plowed } \\
\text { at }\end{array}$ & $\begin{array}{c}\text { Subsoiled } \\
\text { at }\end{array}$ & No-tillage \\
& $40 \mathrm{~cm}$ & $25 \mathrm{~cm}$ & $40 \mathrm{~cm}$ & \\
$0-5$ & & & & \\
$5-10$ & 1.5 & 1.0 & 1.0 & 3.0 \\
$10-14$ & 2.5 & 1.5 & 2.0 & 4.0 \\
$15-20$ & 3.0 & 3.0 & 3.0 & 5.0 \\
$20-25$ & 3.52 & $3.0^{2}$ & $3.0^{2}$ & 3.5 \\
$25-30$ & 4.0 & 3.53 & 3.5 & 3.5 \\
$30-35$ & 2.5 & 5.0 & 3.0 & 4.0 \\
$35-40$ & $3.0^{3}$ & 4.0 & $2.5{ }^{3}$ & 4.5 \\
$40-45$ & 4.0 & 4.0 & 3.5 & 4.0 \\
\end{tabular}

1 Hammer penetrometer specifications: cone base diameter $1 \mathrm{~cm}$, cone apex angle 30 degrees, hammer weight $2 \mathrm{~kg}$, height of fall $50 \mathrm{~cm}$.

2 Depth of cultivation pan; ${ }_{3}$ Depth of autumn tillage. 
Table 8 Grain sorghum yields obtained on various tillage practices

\begin{tabular}{|c|c|c|c|c|c|c|}
\hline \multirow[t]{3}{*}{$\begin{array}{l}\text { Tillage } \\
\text { treatment }\end{array}$} & \multirow{3}{*}{$\begin{array}{l}\text { Depth of } \\
\text { tillage } \\
(\mathrm{cm})\end{array}$} & \multirow{3}{*}{$\begin{array}{c}\text { Winter weed } \\
\text { control-seedbed } \\
\text { preparation }\end{array}$} & \multicolumn{4}{|c|}{$\begin{array}{c}\text { Grain yields of hybrid sorghum } \\
\text { (Hazera 726) }\end{array}$} \\
\hline & & & \multicolumn{2}{|c|}{ Field 1,1967} & \multicolumn{2}{|c|}{ Field 11,1968} \\
\hline & & & $\mathrm{kg} / \mathrm{ha}$ & $\%$ & $\mathrm{~kg} / \mathrm{ha}$ & $\%$ \\
\hline Plowed & 40 & cultivated - harrow & 4386 & 100.0 & 2464 & 90.3 \\
\hline Plowed & 25 & cultivated - harrow & 4167 & 95.0 & 2303 & 84.4 \\
\hline Subsoiled & 40 & cultivated - harrow & 3980 & 90.7 & 2711 & 99.4 \\
\hline No-tillage & - & Atrazine & 2666 & 60.8 & 2728 & 100.0 \\
\hline \multicolumn{3}{|c|}{ Total precipitation in $\mathrm{mm}$} & \multicolumn{2}{|c|}{$1966 / 67: 609$} & \multicolumn{2}{|c|}{$1967 / 68: 461$} \\
\hline
\end{tabular}

The shallow rooting of the no-tillage certainly limits the amount of soil moisture available to the plant, which is reflected in an earlier maturing and dying off of the plants. In the sorghum crop on the no-tillage treatment this is characterized by an earlier firing of the leafs, smaller leaf diameter and smaller tassels. In the cotton crop on no-tillage by smaller plants and less bolls per plant than on the tilled treatments.

Further it should be mentioned that when the need arises for an interrow cultivation, a large amount of stubble left on the no-tillage field may lead to difficulties in performing a satisfactory cultivation. It seems wise to limit the amount of stubble by baling the wheat straw after harvesting. This enables the farmer to carry out interrow cultivations as the cheapest means to control persistent weeds during the growing season and to obtain a soil mulch to suppress the early cracking of the soil (Stibbe and Ariel, 1968).

Yield performance of no-tillage compared to tilled fields

Yield results from no-tillage treatment compared to tillage treatments on replicated field experiments on a grumusol type ${ }^{1}$ of soil on two different locations, show the dependency of the amount of rainfall and accumuulated soil moisture on the grain sorghum yields in the southern part of the country (Hillel et al., 1969).

In Table 8 the grain sorghum yield of 1967 with a sufficient amount of winter rainfall was significant $(1 \% \mathrm{LSD}=1031)$ lower for the no-tillage treatment than for the tillage treatments. However the year 1968, with a lower amount of rainfall and an overall lower yield, shows no significant differences $(5 \%$ LSD $=477)$ between the yields of the various tillage and no-tillage treatments. Only a trend exists that the plowed treatments are somewhat inferior in yield performance to subsoiled and notillage treatments as a result of lower moisture content of the topsoil layer at the start of the growing season.

With similar tillage experiments on a grumusol-type of soil in the northern part of the country having a sufficient amount of rainfall, a significant lower seed-cotton yield

1 Soil type

Mechanical analysis in \%

$\begin{array}{lccccc} & \text { clay } & \text { silt } & \text { fine sand } & \text { coarse sand } & \begin{array}{c}\% \\ \mathrm{CaCO}_{3}\end{array} \\ \text { Grumusol south } & 35.2 & 12.0 & 43.7 & 9.1 & 9.5 \\ \text { Grumusol north } & 64.0 & 23.0 & 10.9 & 2.1 & 11.8\end{array}$


Table 9 Seed cotton yields obtained on various tillage treatments

\begin{tabular}{|c|c|c|c|c|c|c|}
\hline \multirow[t]{3}{*}{$\begin{array}{l}\text { Tillage } \\
\text { treatment }\end{array}$} & \multirow{3}{*}{$\begin{array}{l}\text { Depth of } \\
\text { tillage } \\
(\mathrm{cm})\end{array}$} & \multirow{3}{*}{$\begin{array}{c}\text { Winter weed } \\
\text { control-seedbed } \\
\text { preparation }\end{array}$} & \multicolumn{4}{|c|}{$\begin{array}{l}\text { Seed cotton yields } \\
(\text { Acala } C-1517)\end{array}$} \\
\hline & & & \multicolumn{2}{|c|}{ Field 1,1969} & \multicolumn{2}{|c|}{ Field $I I, 1970$} \\
\hline & & & $\mathrm{kg} / \mathrm{ha}$ & $\%$ & $\mathrm{~kg} / \mathrm{ha}$ & $\%$ \\
\hline Plowed & 40 & Fluometuron - harrow & 1630 & 100.0 & 1497 & 100.0 \\
\hline Plowed & 25 & Fluometuron - harrow & 1457 & 89.3 & 1430 & 95.5 \\
\hline Subsoiled & 40 & Fluometuron - harrow & 1562 & 95.7 & 1181 & 78.9 \\
\hline No-tillage & - & Fluometuron & 1384 & 84.9 & 1235 & 82.5 \\
\hline \multicolumn{3}{|c|}{ Total precipitation in $\mathrm{mm}$} & \multicolumn{2}{|c|}{$1968 / 69: 1088$} & \multicolumn{2}{|c|}{$1969 / 70: 619$} \\
\hline
\end{tabular}

in $1969(1 \%$ LSD $=139)$ and in $1970(1 \%$ LSD $=228)$ for no-tillage was obtained than for the plowed at $40 \mathrm{~cm}$ treatment (see Table 9). The existing tillage pan in the fisld of 1969 at a depth of about $30 \mathrm{~cm}$ was to such a degree compacted that subsoiling at $40 \mathrm{~cm}$ had an immediate effect above that of plowing at $25 \mathrm{~cm}$ (Stibbe and Ariel, 1970). However the tillage pan in the field of 1970 was less problematic and plowing at $25 \mathrm{~cm}$ appeared better than subsoiling at $40 \mathrm{~cm}$.

The yield difference between no-tillage and plowing at $40 \mathrm{~cm}$ expressed in net return will be still more convincing to choose the better and more expensive tillage, since cotton is a high-value crop, contrary to the low net return of a sorghum crop. Simply stated, the invested money in tillage prior to dry-land cotton growing pays off when rainfall is sufficient and a tillage depth with regard to soil moisture conditions is chosen, which prevents compaction or decreases existing compacted layers in the tillage zone. Under conditions where tillage has the tendency to compact the soil, for instance with late tillage after the first rains, yields equal and higher can be obtained from no-tillage fields as compared to tilled fields. This was found on several observation plots with a sorghum crop in the same area (Stibbe and Ariel, 1969).

The earlier maturity of the sorghum and cotton crops on no-tillage fields has a significant, though small effect on the quality of the final products (see Table 10).

The residual effects of tillage and no-tillage on the yields of follow-up crops after sorghum

In the dry-land crop sequence of sorghum-wheat-vetch for hay of the field trials conducted in the southern part of the country, additional information on the yields of the follow-up crops on the various tillage treatments was obtained. The seedbed preparation after the sorghum harvest consisted of disking (disk harrow) followed by planting wheat (Triticum aestivum) after the first rains. The same holds for the seedbed preparation on wheat stubble prior to the planting of vetch the next winter.

Table 10 Influence on the quality of the final products by tillage practices

\begin{tabular}{lcc}
$\begin{array}{l}\text { Tillage } \\
\text { treatment }\end{array}$ & $\begin{array}{c}\text { 1000-grain weight } \\
\text { of sorghum } \\
(1967)\end{array}$ & $\begin{array}{c}\text { Lint (\%) of } \\
\text { seed cotton } \\
(1969)\end{array}$ \\
Plowed $40 \mathrm{~cm}$ & 29.4 & 39.2 \\
No-tillage & 27.4 & 38.7 \\
\hline
\end{tabular}


Table 11 Wheat grain and dry matter vetch yields as follow-up crops after sorghum (Table 8)

\begin{tabular}{|c|c|c|c|c|c|c|c|c|c|}
\hline \multirow{3}{*}{$\begin{array}{l}\text { Tillage } \\
\text { treatment } \\
\text { prior to } \\
\text { sorghum crop }\end{array}$} & \multirow{3}{*}{$\begin{array}{l}\text { Depth of } \\
\text { tillage } \\
(\mathrm{cm})\end{array}$} & \multicolumn{4}{|c|}{$\begin{array}{c}\text { Field I } \\
\text { after sorghum } 1967\end{array}$} & \multicolumn{4}{|c|}{$\begin{array}{c}\text { Field II } \\
\text { after sorghum } 1968\end{array}$} \\
\hline & & \multicolumn{2}{|c|}{ wheat 1968} & \multicolumn{2}{|c|}{ vetch 1969} & \multicolumn{2}{|c|}{ wheat 1969} & \multicolumn{2}{|c|}{ vetch 1970} \\
\hline & & $\mathrm{kg} / \mathrm{ha}$ & $\%$ & $k g / h a$ & $\%$ & $\mathrm{~kg} / \mathrm{ha}$ & $\%$ & $\mathrm{~kg} / \mathrm{ha}$ & $\%$ \\
\hline Plowing & 40 & 1771 & 100.0 & 5659 & 96.0 & 2847 & 100.0 & 7330 & 91.9 \\
\hline Plowing & 25 & 1681 & 94.9 & 5898 & 100.0 & 2643 & 92.8 & 7445 & 93.3 \\
\hline Subsoiling & 40 & 1590 & 89.8 & 5815 & 98.6 & 2656 & 93.3 & 7984 & 100.0 \\
\hline No-tillage & - & 1263 & 71.3 & 5344 & 90.6 & 1970 & 69.2 & 5603 & 70.2 \\
\hline \multicolumn{2}{|c|}{ Total precipitation (mm) } & \multicolumn{2}{|c|}{$67 / 68: 461$} & \multicolumn{2}{|c|}{$68 / 69: 498$} & \multicolumn{2}{|c|}{$68 / 69: 498$} & \multicolumn{2}{|c|}{$\begin{array}{l}69 / 70: 402 \\
\text { irr.: } 100 *\end{array}$} \\
\hline
\end{tabular}

* A supplementary irrigation had to be given to save crop of total failure.

Standard fertilizer applications of $\mathrm{N}$ on wheat and $\mathrm{P}$ on vetch were carried out uniformally over the entire experiments. The yield results of the follow-up crops are given in Table 11 (Hillel et al., 1969).

Some fluctuations in yields of wheat and vetch can be observed on the treatments, which received tillage prior to the sorghum crop. The differences in vetch yields of the tilled treatments were likely caused by the degree of nitrogen and soil moisture depletion by the previous wheat crop, whereas the differences in wheat yields of the tillage treatments were likely more influenced by the differences in soil physical conditions with respect to water infiltration and differences in weed infestation during the wheat-growing season. The differences of the tillage treatments were statistically nonsignificant. On the other hand the wheat and vetch yields of the no-tillage treatment were statistically lower than the yields obtained on the tilled treatments for all the years (wheat 1968 LSD $1 \%=466$, wheat 1969 LSD $1 \%=670$; vetch 1969 LSD $1 \%=298$, vetch 1970 LSD $1 \%=957$ ).

The cause of the lower yields of the follow-up crops on the no-tillage treatment may be sought in a combined effect of a higher degree of weed infestation and less favorable soil conditions. A high degree of weed infestation was also observed in the subsoiled treatments, but the total yields were not so much affected as with no-tillage.

The separation of weeds from subsamples of the vetch crop gave some information about the relative dry matter contribution of weeds to the total dry matter yield per treatment (see Table 12).

Though weeds contribute to the total yields of vetch, the quality of the vetch hay

Table 12 Percentage of dry matter yield of weeds to total dry matter yield of vetch crop

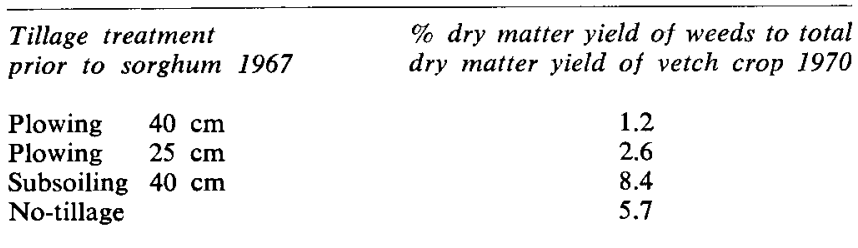


for fodder is lowered in the subsoiled and the no-tillage treatments. To improve the quality of the vetch hay, selective herbicides should have to be applied for weed control, which certainly would add to the production expenses of the crops with a notillage practice.

\section{Conclusion}

In dry-land farming of a semi-arid climate without rainfall during the summer growing season, no-tillage can be practiced on winter fallowed wheat stubble prior to the planting of the summer row crops sorghum and cotton. To obtain best results in weed control, the amount of stubble should be limited to enable efficient herbicidal treatment during the winter season and interrow cultivation during the growing season. Yields of sorghum and cotton on no-tillage in rainfall years with $500 \mathrm{~mm}$ and more are significantly lower than yields on plowed and subsoiled fields. The reason for this is compacted soil layers at shallow depth from previous crops, which impede normal root growth and efficient supply of moisture and nutrients to the growing plants. Only in partial drought years no-tillage can give equal or larger yields than on tilled fields. The effect of no-tillage on the yields of follow-up crops in a three-year crop sequence after sorghum is still felt in generally lower yields and weed control problems as compared to the effect of tilled fields. From the agrotechnical point of view plowing in late summer results in a less urgent need for herbicidal control during winter fallow and in larger yields of summer crops. A positive residual effect was felt in the follow-up winter-grown crops after sorghum. The main problem encountered in plowing dry-land soils in late summer is the high draft requirements necessary to till the soil and the inefficient breaking and turning over of the dry soil with the moldboard plows in use. In order to avoid additional tillages on wet soil during the winter season on compaction-sensitive soils, a number of diskings, rolling and levelling with a plane becomes necessary before the onset of rains. A net return calculation of tilled fields and their yields as compared to a no-tillage practice with its lower yielding capacity might indicate which type of tillage practice is preferable to the farmer.

\section{References}

Army, T. J., A. F. Wiese \& R. J. Hanks, 1961. Effect of tillage and chemical weed control practices on soil moisture losses during the fallow period. Proc. Soil Sci. Soc. Am. 25: 410-413

Bakermans, W. A. P., H. Kuipers \& C. T. de Wit, 1968. Ervaringen met akkerbouw zonder grondbewerking. Landbouwk. Tijdschr. 12: 440-449. (Dutch.)

Harrold, L. L., G. B. Triplett Jr. \& W. M. Edwards, 1970. No tillage corn - characteristics of the system. Agric. Engng 51 : 128-131.

Hillel, D., D. Ariel, S. Orlowski, E. Stibbe, D. Wolf \& A. Yavnai, 1969. Soil - crop - tillage interactions in dryland and irrigated farming. Fin. Tech. Rep. USDA.

Jones Jr., N. J., J. E. Moody \& J. H. Lillard, 1969. Effect of tillage, no-tillage and mulch on soil water and plant growth. Agron. J. $61: 719-721$.

Philips, W. M., 1964. A new technique for controlling weeds in sorghum in a wheat - sorghum fallow rotation in the Great Plains. Weeds 12: 42-44.

Philips, R. E., 1968. Minimum seedbed preparation for cotton. Agron. J. 60: 437-441.

Shear, G. M. \& W. W. Moschler, 1969. Continuous corn by no-tillage and conventional tillage methods; a six year comparison. Agron. J. 61: 524-526.

Stibbe, E. \& D. Ariel, 1968. The influence of row cultivations on dryland sorghum crop. Hassadeh 49: 103-106 (Hebrew). 
Stibbe, E. \& D. Ariel, 1969. Soil tillages for summer crops under dryland farming in the western Emek Yizrael. Hassadeh 49: 695-698 (Hebrew).

Stibbe, E. \& D. Ariel, 1970. The effect of various tillage practices on the soil and on the yield of dryland cotton in the Kishon district. Prel. Rep. Volcani Inst. agric. Res. 664 (Hebrew).

Triplett Jr., G. B., D. M. van Doren Jr. \& B. L. Schmidt, 1968. Effect of corn stover mulch on no-tillage corn yield and water infiltration. Agron. J. 60: 236-239.

Wicks, G. A., C. R. Fenster \& O. C. Burnside, 1969. Herbicide residue in soil when applied to sorghum in a winter wheat-sorghum fallow rotation. Agron. J. 61: 721-724.

Wiese, A. F., E. Burnett \& J. E. Box Jr., 1969. Chemical fallow on dryland cropping sequences. Agron. J. 59: 175-177. 